\title{
Multiple Lipolysis Defects in the Insulin Resistance (Metabolic) Syndrome
}

\author{
Signy Reynisdottir, Karin Ellerfeldt, * Hans Wahrenberg, Hans Lithell, * and Peter Arner \\ Department of Medicine and Research Center, Huddinge University Hospital, Karolinska Institute, S-14186 Stockholm, Sweden; and \\ ${ }^{*}$ Kungsgärdets Hospital, Uppsala University, S-75238 Uppsala, Sweden
}

\begin{abstract}
Bearing in mind the importance of upper-body obesity for the insulin resistance (or metabolic) syndrome and the abnormalities in free fatty acid metabolism associated with this disorder, the regulation of lipolysis in isolated subcutaneous adipocytes was investigated in 13 72-yr-old upper-body obese men with insulin resistance and glucose intolerance and in $\mathbf{1 0}$ healthy 72-yr-old men.
\end{abstract}

There was a marked resistance to the lipolytic effect of noradrenaline in the metabolic syndrome due to defects at two different levels in the lipolytic cascade. First, an $\mathbf{8 0}$-fold decrease in sensitivity to the $\beta 2$-selective agonist terbutaline ( $P$ $<0.001$ ) which could be ascribed to a $50 \%$ reduced number of $\beta 2$-receptors $(P<0.005)$ as determined with radioligand binding. The groups did not differ as regards dobutamine $(\beta 1)$ or clonidine $(\alpha-2)$ sensitivity, nor $\beta 1$-receptor number. The mRNA levels for $\beta 1$ - and $\beta 2$-receptors were similar in the two groups.

Second, the maximum stimulated lipolytic rate was markedly reduced in the metabolic syndrome. This was true for isoprenaline (nonselective $\beta$-agonist), forskolin (activating adenylyl cyclase), and dibutyryl cAMP (activating protein kinase).

In regression analysis, the observed abnormalities in lipolysis regulation correlated in an independent way with the degree of glucose intolerance $(r=-0.67)$ and $\beta 2$-receptor number with insulin resistance $(r=0.67)$.

In conclusion, the results of this study indicate the existence of lipolytic resistance to catecholamines in the adipose tissue of elderly men with the metabolic syndrome, which may be of importance for impaired insulin action and glucose intolerance. The resistance is located at a posttranscriptional level of $\beta 2$-receptor expression and at the protein kinase-hormone sensitive lipase level. (J. Clin. Invest. 1994. 93:2590-2599.) Key words: catecholamines $\bullet$ adipocytes $\bullet$ adrenergic receptors $\bullet$ hormonesensitive lipase $\bullet$ diabetes mellitus

\section{Introduction}

Upper-body obesity is an important risk factor for the development of hypertension, dyslipidemia, and non-insulin-dependent diabetes mellitus (NIDDM) $)^{1}(1,2,3)$. Several of these

1. Abbreviations used in this paper: $\mathrm{BMI}$, body mass index; $\mathrm{M} / \mathrm{I}$, insulin sensitivity index; NIDDM, non-insulin-dependent diabetes mellitus; OGT, oral glucose tolerance; OGTT, OGT test; TNA, total nucleic acids.

Address all correspondence to Peter Arner, M.D., Department of Medicine, Huddinge University Hospital, S-141 86 Huddinge, Sweden.

Received for publication 17 September 1993 and in revised form 14 December 1993.

J. Clin. Invest.

(c) The American Society for Clinical Investigation, Inc.

$0021-9738 / 94 / 06 / 2590 / 10 \$ 2.00$

Volume 93, June 1994, 2590-2599 conditions occur simultaneously and have been recognized as the insulin resistance or "metabolic" syndrome as discussed (4, $5,6)$.

Pathophysiological research on the metabolic syndrome has mainly focused on the interactions of insulin with various aspects of metabolism. A recent finding, for example, is that of a defect in glycogen-synthase function in NIDDM patients (7) which may be genetic (8). However, other mechanisms, not directly related to insulin action, may also be of importance. For example, changes in the action of catecholamines, the major insulin-counteracting hormones, can be involved as well. Increased sympathetic nervous system activity is associated with insulin resistance (9) and altered sympathetic activity may be present in the metabolic syndrome $(4,10)$.

The development and maintenance of obesity plays a central role in the metabolic syndrome. Central obesity may be a predominant factor for the insulin resistance in the metabolic syndrome (11-16). Adaptation to the life style of the industrialized world is associated with an increased incidence of obesity and the metabolic syndrome in Pima indians and Australian aborigines as discussed (17).

The mechanism behind the development of upper-body obesity is unknown but it may be the result of defects in the breakdown of triglycerides in adipocytes during lipolysis, considering that these lipids constitute $>95 \%$ of the total adipocyte weight. In humans, catecholamines are the most important lipolytic hormones, as previously reviewed (18). Lipolysis in subcutaneous fat cells is stimulated via $\beta 1$ and $\beta 2$ adrenoceptors, initiating a chain of events finally activating hormone sensitive lipase (HSL). A counterregulatory system causing inhibition of lipolysis is mediated via $\alpha-2$ adrenoceptors.

In the present study, lipolysis regulation in abdominal fat cells was studied in elderly male subjects with several manifestations of the metabolic syndrome (abdominal obesity, insulin resistance, glucose intolerance, and in some cases hypertension) and in healthy non-obese controls. Catecholamine induced lipolysis was investigated in vitro and the results were related to glucose tolerance and insulin sensitivity.

\section{Methods}

Subjects. The subjects were recruited among 72-yr-old men, all living in the same town for at least 20 years, identified during an ongoing health screening program (13). 13 subjects with the metabolic syndrome were selected for the study. The following inclusion criteria were used: body mass index $(B M I)>26 \mathrm{~kg} / \mathrm{m}^{2}$, waist-hip ratio $>0.93$, insulin resistance as determined with an euglycemic hyperinsulinemic clamp, with an $\mathrm{M} / \mathrm{I}$ value (insulin sensitivity index) of $<4.2(\mathrm{mg} / \mathrm{kg} /$ $\mathrm{min} / \mathrm{mU} / \mathrm{l}$ ) indicating a high level of insulin resistance to glucose uptake and either impaired oral glucose tolerance $(n=8)$, or mild NIDDM (i.e., symptom-free fasting hyperglycemia, but no glucosuria) $(n=5)$. None had received any form of antidiabetic therapy before the study. Three of the subjects were treated for essential hypertension with calcium antagonists, and one subject was on pharmacological treatment of hyperlipidemia with a fibrate, otherwise the subjects were drug free. Ten non-obese healthy and drug free subjects with normal insulin 
sensitivity and normal tolerance to an oral glucose load comprised a control group. The $\mathrm{M} / \mathrm{I}$ value in this group was $>5.5$ and the BMI $<24 \mathrm{~kg} / \mathrm{m}^{2}$.

The clinical characteristics of the two groups are shown in Table I. All subjects had given their informed consent before entering the study. The study was approved by the ethic's committee of the Karolinska Institute and Uppsala University.

The subjects were examined in the fasting state at 8:00 a.m. on three different occasions. Insulin sensitivity was determined on the first occasion, glucose tolerance on the second. On the third occasion, the subjects first rested in the supine position for $10 \mathrm{~min}$. Blood pressure was then measured with a mercury sphygmomanometer on the right arm. The systolic and diastolic pressure was determined by phases I and V of the Korotkov sounds, the values are means of three consecutive measurements. After that venous blood samples for analysis of hormones and metabolites were drawn. A subcutaneous fat specimen of $\sim 2-4 \mathrm{~g}$ was then surgically removed in the paraumbilical region as described (19). The tissue was transported to the laboratory in saline at $37^{\circ} \mathrm{C}$.

Insulin clamp and glucose tolerance test. To determine the degree of insulin sensitivity an euglycemic hyperinsulinemic clamp was performed (13). A priming infusion of insulin was given during the first 10 min, followed a continuous infusion at the rate of $56 \mathrm{mU} / \mathrm{m}^{2}$ was given during $110 \mathrm{~min}$, resulting in a plasma insulin concentration of between 60 and $132 \mathrm{mU} / \mathrm{l}$. The target plasma glucose concentration during the clamp was $5.3 \mathrm{mmol} / \mathrm{l}$. This was reached within $60 \mathrm{~min}$ from the start of the insulin infusion in each subject and was maintained by a continuous infusion of glucose. An insulin sensitivity index $(M / I)$ was obtained by dividing the $\mathrm{M}$-value, i.e., the rate of glucose infusion during the second hour of the clamp ( $\mathrm{mg}$ glucose $/ \mathrm{kg}$ body weight $/ \mathrm{min}$ ), by the steady state insulin concentration $(\mathrm{mU} / \mathrm{l})$ during the second hour of the clamp.

Glucose tolerance was measured with an oral glucose tolerance test (OGTT) on a second occasion. First, blood was drawn from an indwelling catheter for analysis of fasting plasma glucose and insulin levels. The subjects were then given $75 \mathrm{~g}$ of glucose dissolved in water to drink. New samples for plasma glucose determination were taken $120 \mathrm{~min}$ after the oral glucose load.

Table I. Clinical Characteristics

\begin{tabular}{lccc}
\hline & $\begin{array}{c}\text { Metabolic } \\
\text { syndrome }(n=13)\end{array}$ & $\begin{array}{c}\text { Control } \\
\text { state }(n=10)\end{array}$ & $P$ \\
\hline BMI (kg/m2) & $29.8 \pm 0.7$ & $21.9 \pm 0.5$ & \\
W/H ratio & $0.995 \pm 0.01$ & $0.885 \pm 0.01$ & \\
Syst BP (mmHg) & $152 \pm 5$ & $145 \pm 6$ & NS \\
Diast BP (mmHg) & $93 \pm 3$ & $81 \pm 2$ & $<0.005$ \\
Heart Rate (beats/min) & $58 \pm 4$ & $61 \pm 3$ & NS \\
M/l (mg/kg/min/mU/l) & $2.4 \pm 0.3$ & $7.4 \pm 0.4$ & \\
Insulin (mU/l) & $17.6 \pm 3.4$ & $5.3 \pm 0.6$ & $<0.005$ \\
Insulin (OGTT) & $124.3 \pm 18.9$ & $31.7 \pm 5.1$ & $<0.0005$ \\
Glucose (mmol/l) & $5.8 \pm 0.2$ & $5.0 \pm 0.2$ & $<0.05$ \\
OGT (mmol/l) & $10.5 \pm 0.8$ & $5.4 \pm 0.5$ & \\
Triglycerides (mmol/l) & $1.8 \pm 0.2$ & $1.6 \pm 0.1$ & NS \\
Cholesterol (mmol/l) & $6.0 \pm 0.2$ & $6.1 \pm 0.2$ & NS \\
HDL-Cholesterol (mmol/l) & $1.0 \pm 0.1$ & $1.0 \pm 0.1$ & NS \\
Glycerol $(\mu$ mol/l) & $83.3 \pm 9.2$ & $69.4 \pm 9.8$ & NS \\
Free fatty acids $(\mathrm{nmol} / \mathrm{l})$ & $0.57 \pm 0.05$ & $0.44 \pm 0.06$ & NS \\
Noradrenaline $(\mathrm{nmol} / \mathrm{l})$ & $3.3 \pm 0.4$ & $3.5 \pm 0.5$ & NS \\
Adrenaline (nmol/l) & $0.24 \pm 0.04$ & $0.21 \pm 0.03$ & NS \\
Cell volume (pl) & $655 \pm 28$ & $361 \pm 53$ & $<0.0001$ \\
\end{tabular}

OGT, Glucose values $120 \mathrm{~min}$ after oral glucose load (OGTT) and insulin (OGTT) is the value at $120 \mathrm{~min}$. All other hormone and metabolite values are fasting values. The values are mean \pm SEM. They were compared using $t$ test.
Isolation of fat cells and determination of fat cell size and number. The adipose tissue was cut into small fragments (10-20 mg) and isolated fat cells were prepared from the fat specimens by collagenase treatment as described by Rodbell (20). The cells were kept in an albumin buffer solution as described below and the cell density of the adipocyte suspension was kept constant through slow stirring with the aid of a magnet. Direct microscopic determination of the fat cell diameter was performed according to the method of di Girolamo et al. (21). An aliquot of the fat cell suspension was placed on a glass slide and the diameter of 100 cells was determined by examination with a Zeiss microscope equipped with a caliper scale. The coefficient of variation calculated from 10 consecutive determinations of the mean cell size was $3 \%$. The same values were obtained when 200 cells were examined. Mean fat cell volume and weight were determined, taking into consideration the skeweness in the distribution of the cell diameter, using the methods described by Hirsch and Gallian (22). The total lipid content in each incubation was determined gravimetrically after organic extraction. Assuming that lipids constitute $>95 \%$ of the fat cell weight, the number of fat cells in each incubate can be calculated by dividing the total lipid weight with the mean cell weight. This well established method of determining cell number was compared with a much more tedious but direct method developed by Kather et al. (23). The cell number was determined by counting all cells in appropriately diluted aliquots $(10 \mu \mathrm{l})$ of cell suspensions. The coefficient of correlation between the two methods as determined with linear regression analysis was $0.97(n=10)$.

Lipolysis experiments. This assay has previously been described in detail (24). A diluted suspension of isolated fat cells $(5,000-10,000$ cells $/ \mathrm{ml}$ ) was incubated in duplicate in $0.2 \mathrm{ml}$ with or without increasing concentrations of either the natural catecholamine noradrenaline, the nonselective $\beta$-adrenergic agonist isoprenaline, the $\beta 2$-selective agonist terbutaline, the $\beta 1$-selective agonist dobutamine, the $\alpha 2$-selective agonist clonidine, forskolin (which stimulates the adenylyl cyclase), or dibutyryl cyclic AMP (dcAMP) (which is a phosphodiesterase resistant cAMP analogue). All incubations were performed in duplicate at $37^{\circ} \mathrm{C}$ in Krebs Ringer phosphate buffer, $\mathrm{pH} 7.4$, supplemented with bovine serum albumin $(20 \mathrm{~g} / 1)$, glucose $(1 \mathrm{~g} / 1)$, and ascorbic acid $(0.1 \mathrm{~g} / 1)$. In the clonidine experiments adenosine deaminase $(1 \mathrm{mU} / \mathrm{l})$ was added to the incubation medium to remove traces of adenosine which might interfere with the antilipolytic effect of clonidine. This addition was not necessary in the experiments with the lipolytic agents as previously discussed (25). After $2 \mathrm{~h}$, an aliquot was removed for determination of glycerol, which was used as lipolysis index, with an ultrasensitive automated bioluminescence assay (26).

All agonists caused a dose-dependent stimulation or inhibition of glycerol release reaching a plateau at the highest agonist concentrations. We have previously shown that terbutaline and dobutamine are selective and full $\beta$-adrenergic agonists in subcutaneous human fat cells (27). The sensitivity to agonist action was defined as the $\mathrm{pD} 2$ value, i.e., the negative logarithm of the ED50 value, defined as the concentration of each drug giving half maximum effect. The ED50 value was determined using linear regression analysis of log-logit transformation of the individual dose-response curves. Lipolysis rates in the absence of or in the presence of maximum effective agonist concentrations were related to fat cell number, or lipid weight of the incubated fat cells. The maximum lipolytic effects are indicative of agonist responsiveness.

Radioligand binding assay. The receptor binding studies were also performed on isolated fat cells as has been described in detail (28). The nonselective $\beta$-adrenergic antagonist ${ }^{125} \mathrm{I}$-cyanopindolol was used in saturation and displacement experiments. Fat cells were incubated for $60 \mathrm{~min}$, in a concentration of about 20,000 cells $/ \mathrm{ml}$, at $37^{\circ} \mathrm{C}$ in $0.5 \mathrm{ml}$ of KRP buffer, $\mathrm{pH} 7.4$, with bovine serum albumin $(5 \mathrm{~g} / 1)$, glucose ( 1 $\mathrm{g} / \mathrm{l})$ and ascorbic acid.

In the saturation experiments the fat cells were incubated with 10 , $50,100,250,500$, and $750 \mathrm{pmol} / 1$ of ${ }^{125} \mathrm{I}$-cyanopindolol. The incubations were performed in duplicate. In a third set of tubes nonspecific binding was determined by addition of propranolol $(0.1 \mu \mathrm{mol} / 1)$. This was $30 \%$ at low and $45 \%$ at high radioligand concentrations, respec- 
tively. The total amount of radioactivity was determined in a fourth row of cell-free tubes. At the end of the incubation, cell bound radioactivity was measured after addition of ice-cold saline and filtering through a Whatman GF/C filter (Whatman Inc., Clifton, NJ).

In the displacement experiments ${ }^{125} \mathrm{I}$-cyanopindolol binding ( 100 $\mathrm{pmol} / 1$ ) was displaced by the highly selective $\beta 2$-adrenoceptor antagonist ICI 118,551 in 12 increasing concentrations $\left(0,10^{-11}-10^{-4} \mathrm{~mol} /\right.$ 1). Nonspecific binding, defined as the binding in the presence of $10^{-4}$ $\mathrm{mol} / 1$ of ICI 118,551 , was $\sim 30 \%$.

The saturation experiments were evaluated by linear regression analysis of Scatchard plots (29) giving an estimate of the total number of binding sites. The Scatchard plots were always linear, indicating that the radioligand binds to the receptor subtypes with identical affinity. Since the displacing ligand ICI 118,551 binds to $\beta 2$ receptors with high affinity and to $\beta 1$-receptors with low affinity, the displacement experiments gave shallow biphasic curves. A nonlinear least squares regression analysis of the displacement curves provides a statistical comparison between a one- and a two-site model ( 30 ). From the best fitted two site curve it is possible to determine the proportion of binding sites with high-( $\beta 2$-receptors) and low-affinity ( $\beta 1$-receptors) for the displacing ligand, respectively.

Assuming that the concentrations of ${ }^{125} \mathrm{I}$-cyanopindolol used here are not sufficiently high to identify $\beta 3$-receptor binding sites, for which the radioligand has low affinity $(31,32)$ the results of the saturation and displacement experiments can be taken together to provide an estimate of the total number of both $\beta 1$ - and $\beta 2$-receptor binding sites for each subject. The binding assays required large amounts of fat. They could therefore only be performed in 10 obese and eight nonobese subjects, respectively.

$m R N A$ assay. For this assay, which has been described in detail (33), $\sim 150 \mu$ l of isolated fat cells were homogenized and digested with protein kinase, total nucleic acids (TNA) were extracted with phenolchloroform. The amount of DNA and TNA in the extract were determined fluorometrically (34).

Complementary oligonucleotide probes corresponding to nucleotide 739-789 for the $\beta 1$-receptor and to nucleotide $772-822$ for the $\beta 2$-receptor were synthesized and cloned into pGEM-3. This plasmid was then used for in vitro synthesis of cRNA which was radiolabeled with $\left[{ }^{35} \mathrm{~S}\right] \mathrm{UTP}$. The amounts of $\beta 1$ - and $\beta 2$-receptor mRNA in the extract were then determined in duplicate by solution hybridization (35). The assay has previously been described in detail (33). Briefly, $\left[{ }^{35} \mathrm{~S}\right] \mathrm{UTP}$ cRNA was hybridized at $70^{\circ} \mathrm{C}$ to the TNA samples. Nonhybridized material was digested with $\mathrm{RNase}$. RNase resistant material was precipitated and collected on a glass filter. The results of the sample hybridization were compared with hybridization to a known amount of in vitro synthesized $\beta 1$ - and $\beta 2$-receptor mRNA complementary to the radioactive probe. The results were related to the amount of TNA or DNA as described before (36). Previous methodological experiments have shown that the $\beta$-adrenoceptor probes are specific for the investigated species (33) and that the amount of $\beta 1$ - and $\beta 2$-receptor mRNA measured in this assay are proportional to the amount of human fat cell extract added (36).

Statistical analysis. The Student's two-tailed $t$ test was used for comparison of data between groups. In some cases single or multiple stepwise regression analysis was performed. Factor analysis was used in multivariate regression analysis. All values are expressed as mean \pm SE. The values for $K_{\mathrm{d}}$ and ED50 were transformed into their logarithmic form before statistical evaluation. All statistics were performed by means of a software statistical package (Stat View II, Abacus Concepts Inc., Berkeley, CA).

Drugs and chemicals. Bovine serum albumin (fraction V, lot 63F0748), clostridium histiolyticum collagenase type I, propranolol, forskolin, dibutyryl cAMP, and glycerol kinase from $E$. Coli (G4509) were obtained from Sigma Chemical Co. (St. Louis, MO). (-)-Isoprenaline came from Hässle (Mölndal, Sweden), terbutaline from Draco (Lund, Sweden), Dobutamine from Lilly (Indianapolis, IN), and ICI 118,551 from Cambridge Research Biochemicals Limited (Cheshire, UK). ATP monitoring reagent containing firefly luciferase was from LKB
Wallac (Turku, Finland). pGEM-3 was from Promega (Madison, WI), SPG RNA polymerase and T7 RNA polymerase were obtained from Boehringer Mannheim (Mannheim, Germany). ${ }^{35}$ S-UTP and ${ }^{125}$ I-cyanopindolol were from NEN DuPont (Boston, MA). All other chemicals were of the highest grade of purity commercially available. Collagenase and the ingredients in the incubation buffers were from the same batches throughout the study.

Determination of hormones and metabolites. Plasma insulin and catecholamine levels were determined as described (36). Blood glucose and lipid levels were analyzed at the hospitals routine chemistry laboratory.

\section{Results}

The mean lipolysis dose-response curves for noradrenaline and isoprenaline are depicted in Fig. 1. Both agents caused a dose-dependent increase in lipolysis above the basal rate in both groups but the response was clearly reduced in the subjects with the metabolic syndrome. The two upper curves show results per cell number. Due to the almost twofold difference in cell size between groups, the difference in responsiveness was even more marked when lipolysis was expressed per gram lipid, as in the two lower curves in Fig. 1. When lipolysis was stimulated at a postreceptor level with forskolin or dcAMP there was also a dose-dependent stimulation of lipolysis above the basal rate as shown in Fig. 2. A reduction in responsiveness was found in the metabolic syndrome, irrespective of the use of denominator for lipolysis. Again the difference was more marked when lipolysis was expressed per lipid weight.

The maximum lipolytic effects of noradrenaline, isoprenaline, forskolin and dcAMP (obtained from data in Figs. 1 and 2 ) are evaluated in Table II. The difference between the groups was highly statistically significant for all agents irrespective of denominator (per cell or per gram of lipid) when the increase above the basal rate was calculated. The difference was even more marked when lipolysis was expressed per gram of lipid. In the subjects with the metabolic syndrome, responsiveness to isoprenaline, the most effective lipolytic agent, was reduced by $44 \%$ per cell and by as much as $75 \%$ per gram of lipid. Basal lipolysis (no agent added) was significantly increased in the subjects with the metabolic syndrome when expressed per cell but there was no statistical difference between groups when expressed per $\mathbf{g}$ of lipid. Table II also shows data of maximum lipolytic rates with the basal values included. Still, all significant differences between the two groups persisted except that for noradrenaline stimulated lipolysis when expressed per cell. Noradrenaline was, however, only a partial agonist in both groups causing $30-50 \%$ of the isoprenaline action (Table II).

Adrenoceptor sensitivity was determined with the receptorselective agents terbutaline, dobutamine and clonidine. The mean dose-response curves are shown in Fig. 3. They are depicted as percent of the maximum lipolytic effect, which is preferable when half-maximum effects (i.e., sensitivity) are evaluated, and as absolute rates per cell as well. The mean percent dose response curve for the $\beta 2$-agonist terbutaline was shifted markedly to the right in the subjects with the metabolic syndrome while the curves for dobutamine and clonidine were practically superimposed in the two groups. It is also shown in Fig. 3 that the maximum lipolysis rates were reduced with both agents in the metabolic syndrome group although sensitivity (ED50) only differed between groups as regards terbutaline. When calculated on individual data, the maximum increase in lipolysis rate over basal ( $\mu \mathrm{mol}$ glycerol $/ 10^{7}$ cells $)$ with terbuta- 

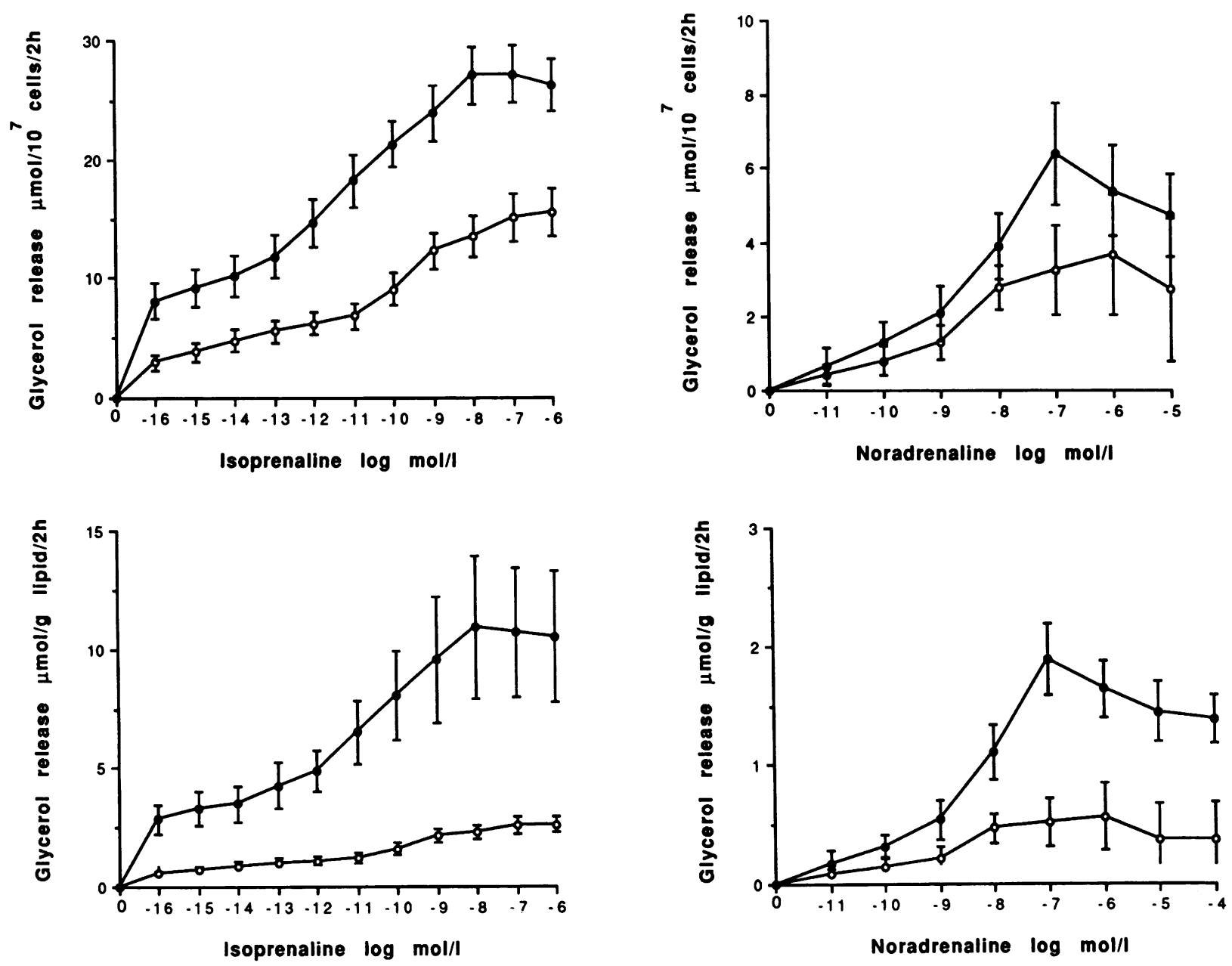

Figure 1. Mean dose-response curves for lipolysis stimulated by noradrenaline and isoprenaline in subjects with the metabolic syndrome ( 0 ) and in healthy control subjects $(\bullet)$. Isolated fat cells were incubated with or without the indicated concentrations of the agent and glycerol release to the medium was measured and used as lipolysis index. Glycerol release was related to cell number ( upper panels) or gram of lipid (lower panels).

line stimulation was $25.1 \pm 2.3$ in control and $13.8 \pm 1.9$ in the metabolic syndrome $(P<0.001)$. The corresponding values for dobutamine were $25.4 \pm 1.8$ and $13.1 \pm 1.8(P<0.0001)$. Similar differences between the groups were observed when the basal values were not subtracted or when lipid weight was used as the denominator instead of cell number (data not shown).

Fig. 4 shows the inhibition of the basal lipolysis rate by clonidine in the two groups. The two curves are almost superimposed. At maximum effective concentrations basal lipolysis was reduced with $67 \pm 8$ and $70 \pm 4 \%$ in the obese and non-obese subjects, respectively (i.e., a reduction to $\sim 30 \%$ of the initial rate).

A statistical comparison of the individual values for adrenoceptor sensitivity expressed as pD2 values is shown in Table III. Sensitivity to terbutaline was 80 -fold reduced in the metabolic syndrome $(P<0.001)$ but there was no significant difference between the $\mathrm{pD} 2$ values for dobutamine or clonidine in the two groups.

Displacement of ${ }^{125} \mathrm{I}$-cyanopindolol by the selective $\beta 2$-antagonist ICI 118,551 is shown in Fig. 5. The mean displacement curves for healthy and obese subjects were clearly biphasic, indicating a high and a low affinity binding component. The mean displacement curve from the group with the metabolic syndrome was markedly shifted to the right as compared to the control group which suggests a decreased proportion of $\beta 2$-receptor binding sites in the insulin resistant state.

The results of the radioligand binding studies in the individual subjects are summarized in Table IV. The subjects with the metabolic syndrome had a $50 \%$ reduced number of $\beta 2$-receptor binding sites $(p<0.005)$ while there were no significant differences in the $\beta 1$-receptor binding capacity per cell. There was no significant difference between the groups as regards receptor affinity for the displacing drug ICI 118,551 (data not shown) or the radioligand $\left(K_{\mathrm{d}}, 92 \pm 20\right.$ and $69 \pm 18 \mathrm{pmol} / 1$ in the metabolic syndrome and in the control group, respectively). The saturation experiments always gave linear Scatchard plots with a Hill coefficient not significantly different from unity, indicating that the radioligand binds to the receptors with equal affinity.

The results of the mRNA assay are also shown in Table IV. There were no significant differences in either $\beta 1$ - or $\beta 2$-receptor mRNA levels between the two groups. This was also true when the results were related to the DNA levels (data not shown). The ratio of $\beta 2 / \beta 1$-receptor binding sites was reduced in the subjects with the metabolic syndrome $(P<0.01)$ while the ratio of $\beta 2 / \beta 1$ receptor mRNA levels was unchanged. Thus, the outcome of the results with mRNA was not dependent upon the mode of expression (TNA, DNA ratio), which 

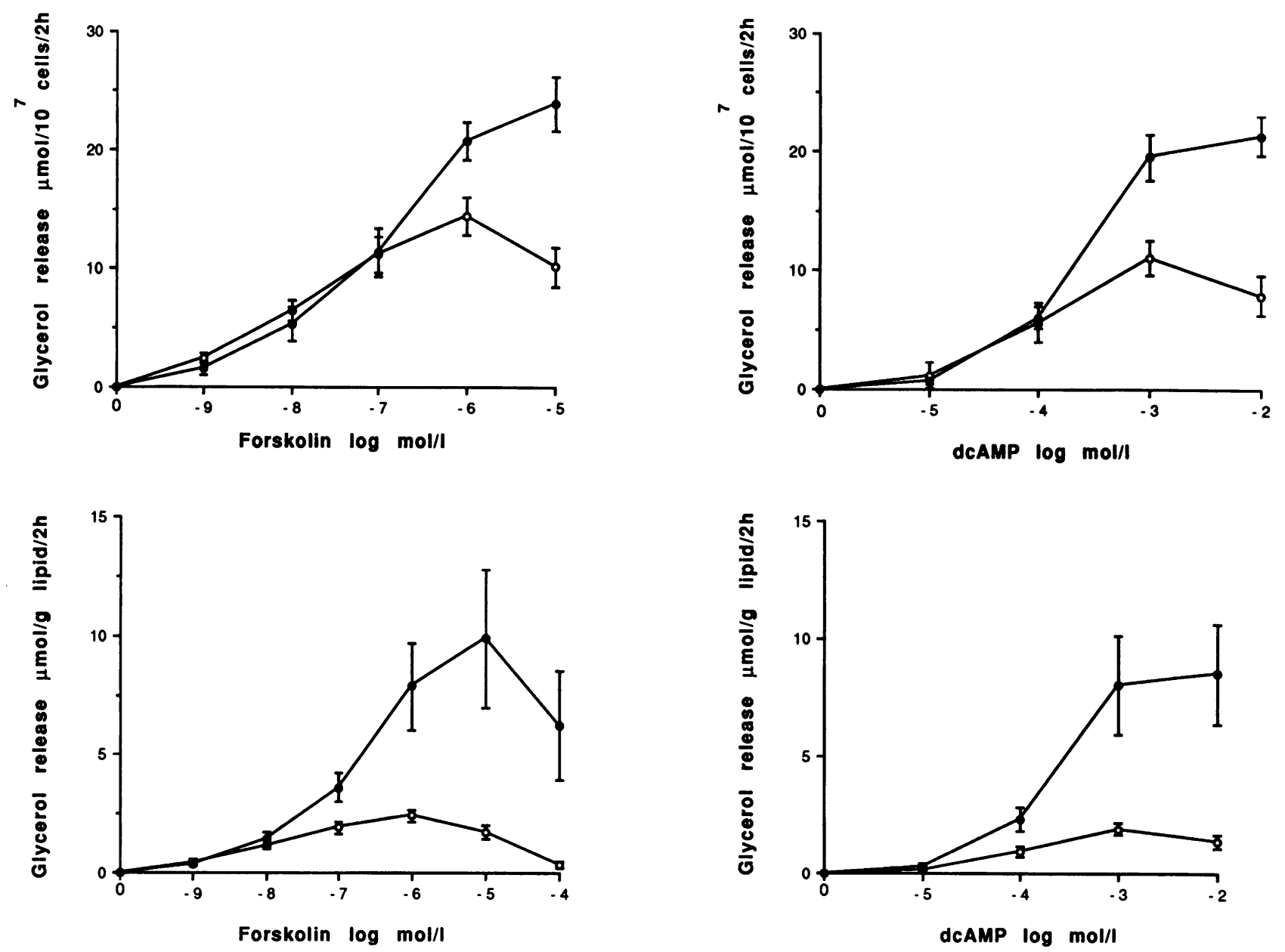

Figure 2. Mean dose-response curves for lipolysis stimulated at postreceptor levels with forskolin and dibutyryl cAMP in subjects with the metabolic syndrome and in healthy controls. Symbols and incubation conditions are as in Fig. 1.

strongly suggests that there were no differences between the groups in the extraction of $\mathrm{mRNA}$ subtypes from the fat cells.

Clinical data are given in Table I. As expected, the obese subjects had higher fasting blood glucose levels and insulin lev- els and a greater increment of plasma insulin after an oral glucose load than the control group. In addition to the three subjects who were on treatment for hypertension, five subjects had blood pressure above the WHO criteria for diagnosis of hyper-

Table II. Lipolysis Rates of Isolated Fat Cells

\begin{tabular}{|c|c|c|c|c|c|c|}
\hline & \multicolumn{6}{|c|}{ Lipolysis rate } \\
\hline & $\begin{array}{l}\text { Metabolic } \\
\text { syndrome }\end{array}$ & $\begin{array}{l}\text { Control } \\
\text { state }\end{array}$ & $P$ & $\begin{array}{l}\text { Metabolic } \\
\text { syndrome }\end{array}$ & $\begin{array}{l}\text { Control } \\
\text { state }\end{array}$ & $P$ \\
\hline & \multicolumn{2}{|c|}{$\mu \mathrm{mol}$ glycerol $/ 10^{7}$ cells } & \multicolumn{4}{|c|}{ $\mu \mathrm{mol}$ glycerol/g lipid } \\
\hline Basal & $7.3 \pm 1.4$ & $3.2 \pm 0.9$ & $<0.05$ & $1.3 \pm 0.3$ & $0.9 \pm 0.2$ & NS \\
\hline Noradrenaline & $10.3 \pm 1.4$ & $10.7 \pm 1.9$ & NS & $1.8 \pm 0.3$ & $3.0 \pm 0.3$ & $<0.01$ \\
\hline Nor minus basal & $3.0 \pm 1.2$ & $7.4 \pm 1.4$ & $<0.05$ & $0.4 \pm 0.2$ & $2.1 \pm 0.3$ & $<0.0001$ \\
\hline Isoprenaline & $23.4 \pm 2.7$ & $31.8 \pm 2.9$ & $<0.05$ & $4.0 \pm 0.5$ & $12.3 \pm 3.1$ & $<0.01$ \\
\hline Iso minus basal & $16.1 \pm 2.0$ & $28.6 \pm 2.5$ & $<0.001$ & $2.7 \pm 0.3$ & $11.3 \pm 3.0$ & $<0.005$ \\
\hline Forskolin & $20.6 \pm 2.5$ & $28.0 \pm 2.4$ & $<0.05$ & $3.5 \pm 0.5$ & $11.1 \pm 2.9$ & $<0.01$ \\
\hline For minus basal & $13.3 \pm 2.0$ & $24.9 \pm 2.2$ & $<0.001$ & $2.5 \pm 0.3$ & $10.1 \pm 2.9$ & $<0.01$ \\
\hline dcAMP & $18.0 \pm 2.4$ & $24.8 \pm 2.0$ & $<0.05$ & $3.1 \pm 0.5$ & $9.6 \pm 2.2$ & $<0.005$ \\
\hline dcAMP minus basal & $10.7 \pm 1.9$ & $21.6 \pm 1.7$ & $<0.001$ & $2.0 \pm 0.3$ & $8.6 \pm 2.2$ & $<0.005$ \\
\hline
\end{tabular}

Lipolysis was determined in the absence (basal) or presence of maximum effective agonist concentrations. The values are shown with or without the value for basal lipolysis rates included. The data are expressed per $10^{7}$ cells and per gram of lipids. The values are mean \pm SEM. They were compared using the unpaired $t$ test. 

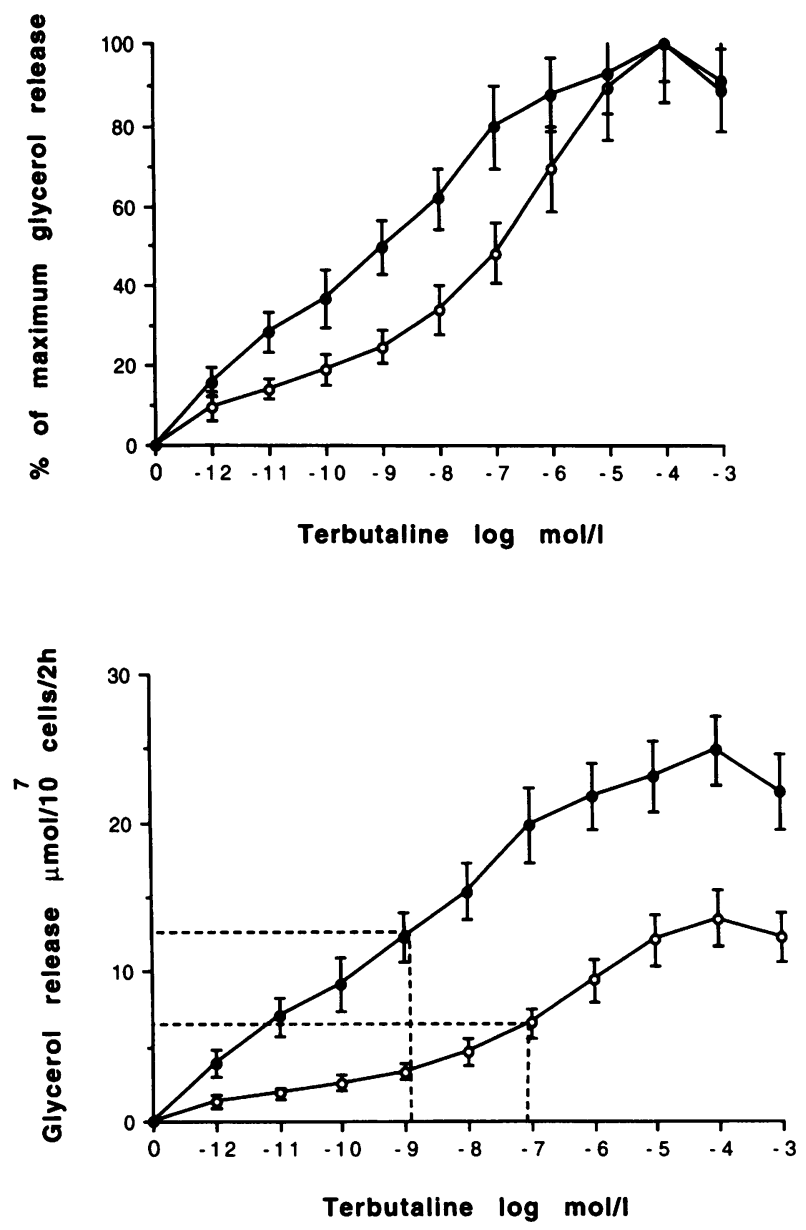
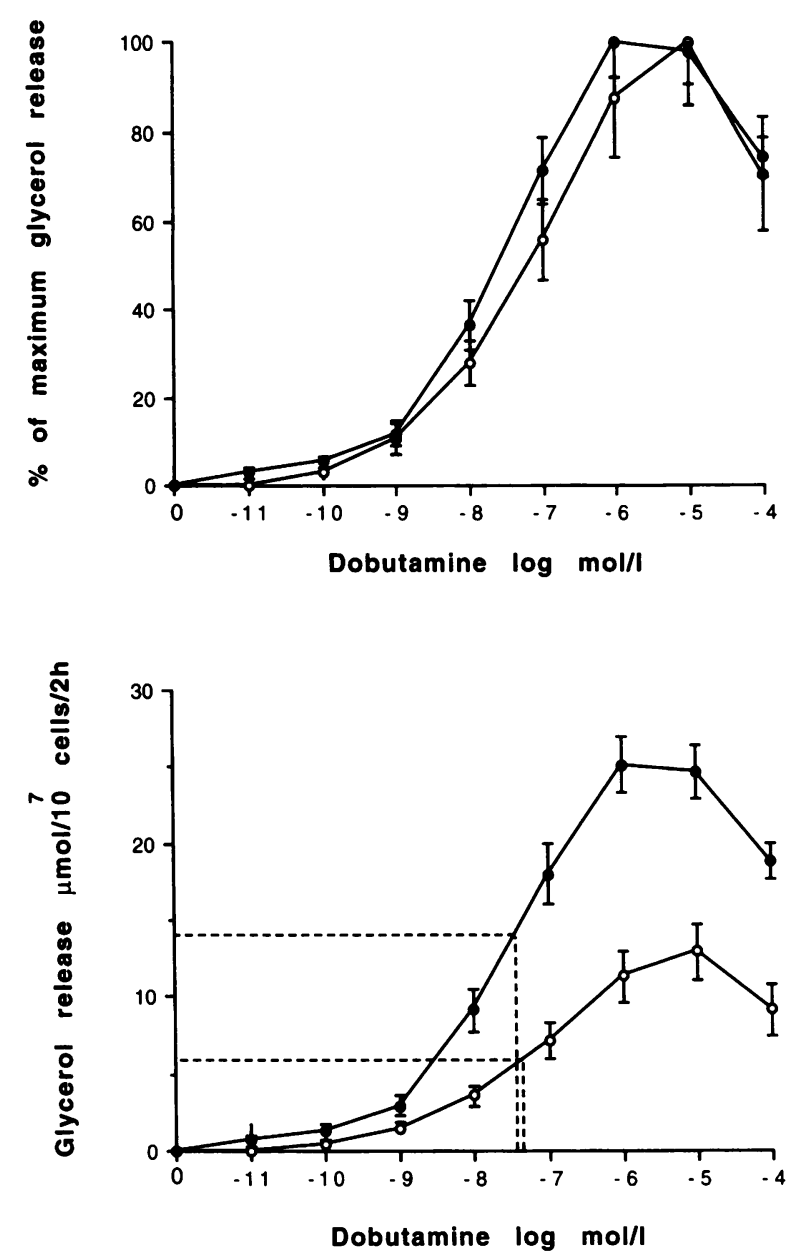

Figure 3. Effect of terbutaline (selective $\beta 2$-agonist) and dobutamine (selective $\beta 1$-agonist) on lipolysis in isolated fat cells from men with the metabolic syndrome and healthy controls. Incubation conditions and symbols are as in Fig. 1. Mean dose-response curves for terbutaline and dobutamine are plotted as percent of maximum lipolysis rate in the upper graphs and as absolute rates minus the basal rates in the lower graphs. The agonist concentration yielding half maximum effect is indicated with broken lines in the lower graphs.

tension. Resting plasma values of catecholamines, glycerol, free fatty acids and other blood lipids were similar in the two groups.

The relationship between clinical signs and the findings with fat cells were investigated using factor analysis. The corre-

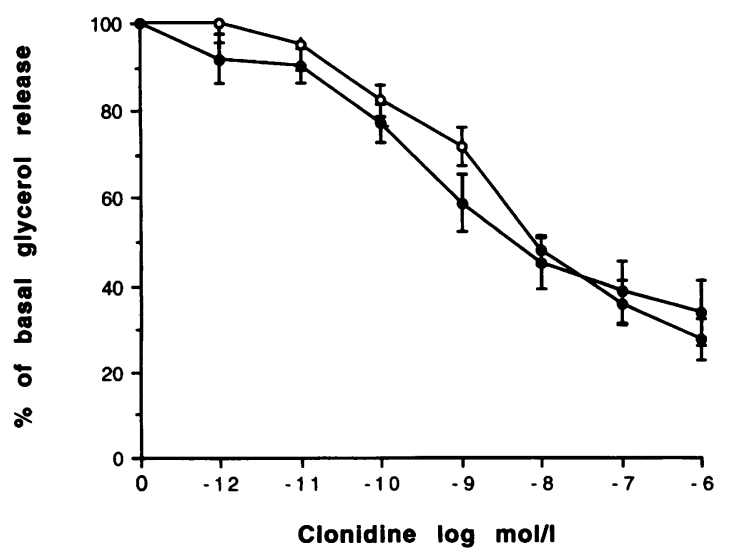

Figure 4. Mean dose-response curves for clonidine-induced inhibition of lipolysis in the metabolic syndrome $(0)$. The curves are plotted as per cent of the basal rate. lation matrix is given in Table $\mathrm{V}$. There was a strong correlation $(-0.6>r>0.6)$ between the degree of glucose intolerance and the basal and maximum stimulated lipolysis rates, $\beta 2$-receptor number, and insulin sensitivity. The insulin sensitivity index correlated strongly $(-0.6>r>0.6)$ with $\beta 2$-receptor number, BMI, cell volume, waist/hip-ratio, fasting plasma insulin levels, and glucose tolerance.

The relationship between glucose intolerance and insulin sensitivity as dependent variables on one hand and the most important clinical and adipocyte data from the factor analysis on the other was further examined with a stepwise regression analysis. The results are summarized in Table VI. In the equation with glucose intolerance as the dependent variable, basal and maximum stimulated lipolysis were the only significant regressors. Adjusted $r^{2}$ was 0.77 for these two variables. In the stepwise regression analysis with insulin sensitivity as the dependent variable, BMI, $\beta 2$-receptor number and fasting plasma insulin contributed significantly to the relationship. The adjusted $r^{2}$ for these regressors taken together was 0.80 .

The linear relationships between glucose tolerance and isoprenaline responsiveness $(r=-0.67)$ and between insulin sensitivity and $\beta 2$-receptor number $(r=0.67)$ are shown in Fig. 6 .

The relationship between the agonist pD2 and receptor number versus fat cell volume and basal lipolysis rate was in- 
Table III. Lipolytic Sensitivity to Selective Adrenergic Agents

\begin{tabular}{lccc}
\hline & \multicolumn{3}{c}{$\mathrm{pD} 2(-\mathrm{Log} \mathrm{mol} / \mathrm{l})$} \\
\cline { 2 - 4 } & Terbutaline & Dobutamine & Clonidine \\
\hline Metabolic syndrome & $7.0 \pm 0.2$ & $7.3 \pm 0.1$ & $9.0 \pm 0.2$ \\
Control state & $8.9 \pm 0.4$ & $7.5 \pm 0.1$ & $9.3 \pm 0.2$ \\
$P$ & $<0.001$ & $\mathrm{NS}$ & $\mathrm{NS}$ \\
\hline
\end{tabular}

The agonist concentration giving half maximum effect on lipolysis was determined from dose response curves. pD2 is the negative logarithm of this value. The values are mean \pm SEM. They were compared using the unpaired $t$ test.

vestigated in linear regression analysis. The only statistically significant relationship was a negative correlation between fat cell volume and pD2 for terbutaline $(r=0.59, P<0.005)$.

Three of the subjects with the metabolic syndrome were treated with calcium channel blockers because of hypertension. The mean values for lipolysis, radioligand binding, mRNA, and clinical parameters were almost identical with the values for the remaining 10 subjects. When data from the latter subjects were compared with the control group, the difference between groups was essentially the same as when the whole material was used.

\section{Discussion}

In this study we have for the first time examined the lipolytic function of adipocytes in the metabolic syndrome. The study was performed on elderly men with upper body obesity, reduced glucose tolerance, or NIDDM insulin resistance, and in some cases hypertension. We found a marked decrease of the catecholamine induced rate of lipolysis in fat cells from these subjects as compared to the adipocytes from healthy non-obese controls. These differences seem to be determined at different levels in the lipolytic cascade: from the binding of the hormone to cell surface adrenoceptors to the hydrolysis of triglycerides by the hormone sensitive lipase producing glycerol and free fatty acids.

As regards adrenoceptor function, the observed catecholamine resistance was entirely due to a $\beta 2$-receptor defect, since sensitivity to the $\beta 2$-selective agonist terbutaline was markedly reduced in the obese while there was no significant difference in the sensitivity to either the $\beta 1$-selective agonist dobutamine or the $\alpha 2$-receptor agonist clonidine between the groups. A corresponding selective reduction by as much as $50 \%$ in the number of $\beta 2$-receptor binding sites was observed in the metabolic syndrome, as evidenced from the findings with radioligand binding. This indicates that low $\beta 2$-receptor density is one major factor for the observed hormone resistance. However, additional defects in $\beta 2$-receptor coupling to Gs protein may contribute as well. Indirect evidence of this is the present observation of a negative correlation between $\beta 2$-receptor sensitivity (but not $\beta 2$-receptor number) and fat cell volume which was increased in the patients with the metabolic syndrome. Unfortunately, it is not possible to study coupling in small amounts of human fat cells with current techniques. The steady state $\beta 1$ and $\beta 2$-mRNA levels and their ratios did not differ between the groups which indicates that the differences in $\beta 2$-receptor number are determined at a posttranscriptional level. To examine these events also requires too large amounts of tissue to be included in a clinical investigation.

Recently, a third $\beta$-adrenoreceptor $(\beta 3)$ has been cloned. It is of major importance for lipolysis in brown fat cells in laboratory animals as discussed (37), but appears to be of less importance for lipolysis regulation in human subcutaneous fat cells $(38,39)$. The effects of the non-selective $\beta$-agonistic agents (noradrenaline, isoprenaline) might possibly be influenced to a minor degree by the presence of $\beta 3$-receptors, but not the action of the $\beta 1$ - and $\beta 2$-selective agents. Radioligand studies on transfected cells expressing human $\beta 3$-receptors have indicated that ${ }^{125}$-ICYP has $10-1,000$ times lower affinity for the $\beta 3$-receptor than for $\beta 1$ - or $\beta 2$-receptors $(31,32)$, therefore we assume that $\beta 3$-receptors can not be detected with the concentrations of the radioligand used in this study as previously shown in human fat cells (38). The unity of the Hill coefficient for the radioligand binding also excludes an important contribution of $\beta 3$-receptors to the binding results.

The second defect in catecholamine effect was the marked suppression of the maximum lipolytic response found in the subjects with the metabolic syndrome (44-75\% reduction, dependent upon the use of denominator for the lipolysis rate). The defect was of similar magnitude when lipolysis was nonselectively stimulated through $\beta$-receptors with isoprenaline, selectively with dobutamine or terbutaline or at different postreceptor levels with forskolin or dcAMP. These data strongly indicate alterations in the most distal steps of the lipolytic pathway, i.e., a decreased ability of cyclic AMP to activate the pro-

Table IV. $\beta$-Adrenoceptor Subtype Expression and $m R N A$ Levels

\begin{tabular}{|c|c|c|c|c|c|c|}
\hline & \multicolumn{3}{|c|}{ Radioligand binding capacity } & \multicolumn{3}{|c|}{ mRNA } \\
\hline & $\beta 1$ & $\beta 2$ & $\beta 2 / \beta 1$ & $\beta 1$ & $\beta 2$ & $\beta 2 / \beta 1$ \\
\hline & pmol/10 $10^{7}$ cells & pmol/10 cells & $\mathrm{pmol} / 10^{7} \mathrm{cells}$ & 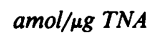 & amol/ug TNA & $a m o l / \mu g$ TNA \\
\hline Metabolic syndrome & $0.57 \pm 0.15$ & $0.39 \pm 0.08$ & $0.81 \pm 0.14$ & $98.9 \pm 19.2$ & $63.5 \pm 13.8$ & $0.62 \pm 0.04$ \\
\hline Control state & $0.61 \pm 0.08$ & $0.85 \pm 0.11$ & $1.42 \pm 0.14$ & $104.1 \pm 24.7$ & $58.8 \pm 13.1$ & $0.65 \pm 0.05$ \\
\hline$P$ & NS & $<0.005$ & $<0.01$ & NS & NS & NS \\
\hline
\end{tabular}

The maximum radioligand binding capacity and the relative proportions of $\beta 1$ - and $\beta 2$-receptor binding sites were determined in saturation and displacement experiments with ${ }^{125} \mathrm{ICYP}$ and $\beta 1$ - and $\beta 2$-adrenoceptor mRNA levels were determined with solution hybridization in 72 -yr-old men with the metabolic syndrome and healthy non-obese controls as described in Methods. The values are mean \pm SEM. They were compared using the unpaired $t$ test. 
Table V. Correlation Matrix for Lipolysis, Clinical Data, and Radioligand Binding

\begin{tabular}{|c|c|c|c|c|c|c|c|c|c|c|}
\hline & $\begin{array}{c}\beta_{2} \text { rec } \\
\text { number }\end{array}$ & $\begin{array}{l}\text { Basal } \\
\text { lipolysis }\end{array}$ & $\begin{array}{c}\text { Max } \\
\text { liplysis }\end{array}$ & BMI & $\begin{array}{c}\text { Cell } \\
\text { volume }\end{array}$ & $\begin{array}{l}\mathrm{W} / \mathrm{H} \\
\text { ratio }\end{array}$ & Insulin & OGT & $\mathbf{M} / \mathbf{I}$ & DBP \\
\hline$\beta 2$ rec number & 1 & & & & & & & & & \\
\hline Basal lipolysis & -0.43 & 1 & & & & & & & & \\
\hline Max lipolysis & 0.62 & 0.05 & 1 & & & & & & & \\
\hline BMI & -0.50 & 0.44 & -0.39 & 1 & & & & & & \\
\hline Cell volume & -0.28 & 0.42 & -0.30 & 0.82 & 1 & & & & & \\
\hline $\mathrm{W} / \mathrm{H}$ ratio & -0.58 & 0.33 & -0.59 & 0.77 & 0.66 & 1 & & & & \\
\hline Insulin & -0.42 & 0.56 & -0.20 & 0.61 & 0.55 & 0.36 & 1 & & & \\
\hline OGT & -0.67 & 0.63 & -0.61 & 0.50 & 0.47 & 0.53 & 0.60 & 1 & & \\
\hline $\mathrm{M} / \mathrm{I}$ & 0.67 & -0.58 & 0.55 & -0.86 & -0.74 & -0.76 & -0.74 & -0.74 & 1 & \\
\hline DBP & -0.55 & 0.35 & -0.48 & 0.65 & 0.37 & 0.38 & 0.34 & 0.34 & 0.60 & 1 \\
\hline
\end{tabular}

Analysis of the linear relationship between the clinical parameters given in the table. DBP, diastolic blood pressure. The values are $r$ values from factor analysis. Data from men with the metabolic syndrome were pooled with healthy controls.

tein kinase-hormone sensitive lipase complex. A more detailed examination of these mechanisms was again not possible in the present study because of the large amounts of tissue required. These findings with maximum lipolytic response were not related to the function of the antilipolytic $\alpha 2$-receptors since both the sensitivity and maximum inhibitory response to the $\alpha 2$-agonist clonidine were similar in the two groups. The latter is in contrast to the findings of Mauriège et al. (40) who demonstrated increased $\alpha 2$-adrenoceptor mediated antilipolysis in abdominal fat cells from obese male subjects. This discrepancy in findings may be a reflection of the large difference in the populations examined in these two studies: young males with uncomplicated obesity as compared with elderly men with the metabolic syndrome. The existence of two different levels of catecholamine resistance is perhaps best demonstrated by the combined findings with terbutaline and dobutamine, which are two selective full agonists (36). The maximum action was decreased with both agonists in the metabolic syndrome but the sensitivity was only altered with terbutaline.

The basal rate of lipolysis was elevated when expressed per cell number in the group with the metabolic syndrome. The

Table VI. Relationship between Dependent and Independent Variables

\begin{tabular}{lrc}
\hline & \multicolumn{2}{c}{ Partial F } \\
\cline { 2 - 3 } Independent variable & M/I & OGT \\
\hline B2-receptor number & 5.8 & 0.03 \\
Basal lipolysis & 0.6 & 34.8 \\
Maximum lipolysis & 2.1 & 32.8 \\
BMI & 18.5 & 0.2 \\
P-Insulin & 5.3 & 1.1 \\
\hline
\end{tabular}

Stepwise regression analysis of the relationship between glucose tolerance $(O G T)$ or insulin sensitivity $(M / I)$ on one hand and lipolysis, $\beta 2$-receptor number, BMI, and fasting plasma $(P)$ insulin on the other hand. Data were obtained from Table V. Results from subjects with the metabolic syndrome and control subjects were pooled together Values are partial $F$ for the parameters which contributed to the variations in glucose tolerance and insulin sensitivity. A statistically significant contribution was defined as partial $F \geq 4$. physiological importance of this finding is, however, uncertain. First, it is unlikely that corresponding conditions, i.e., a total lack of catecholamine effects, exist in vivo. Second, it is well known from previous studies that basal lipolysis in vitro increases with increasing cell size, as reviewed (41). Fat cell volume was increased in the subjects with the metabolic syndrome and the differences between the groups disappeared when lipolysis was expressed per gram of lipid. The maximum lipolytic capacity in contrast, was decreased in the subjects with the metabolic syndrome, irrespective of the use of denominator (cell number, lipid weight). This was true whether the elevated basal lipolysis rates were subtracted or not, except when the lipolytic effect of noradrenaline was expressed per cell number with the basal values included. The latter indicates that the basal lipolysis rate is accelerated in the enlarged adipocytes of patients with the metabolic syndrome as a compensation for the decreased stimulatory effect of the partial agonist noradrenaline. However, the increase in basal lipolysis does not compensate for the decreased effect of the full agonists.

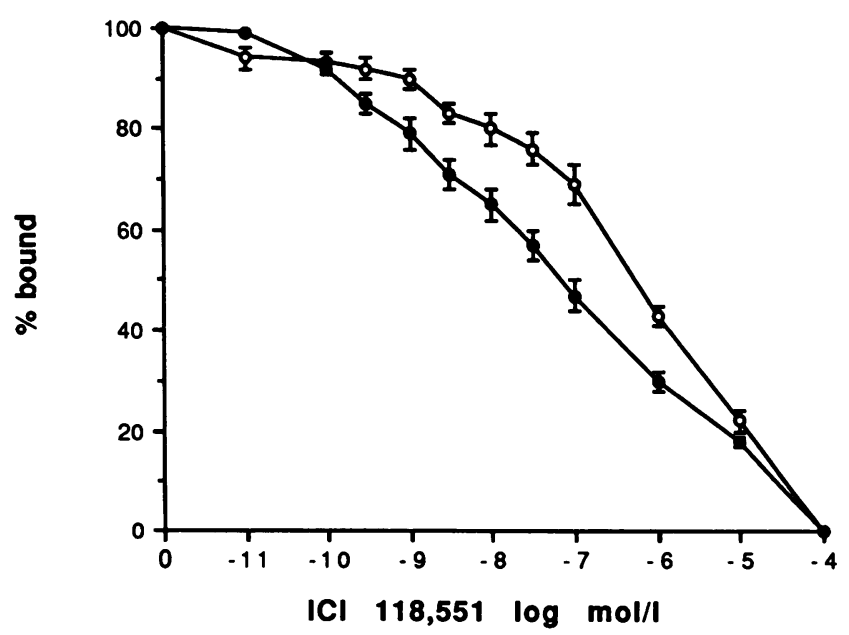

Figure 5. Mean curves for displacement of ${ }^{125} \mathrm{I}$-cyanopindolol binding by the $\beta 2$-selective antagonist ICI 118,551 in subjects with the metabolic syndrome $(0)$ and healthy controls $(\bullet)$. Isolated fat cells were incubated for $60 \mathrm{~min}$ with $100 \mathrm{pM}$ of the radioligand and increasing concentrations of the displacing drug. Data are expressed as percent of total specific binding in absence of the displacing agent. 

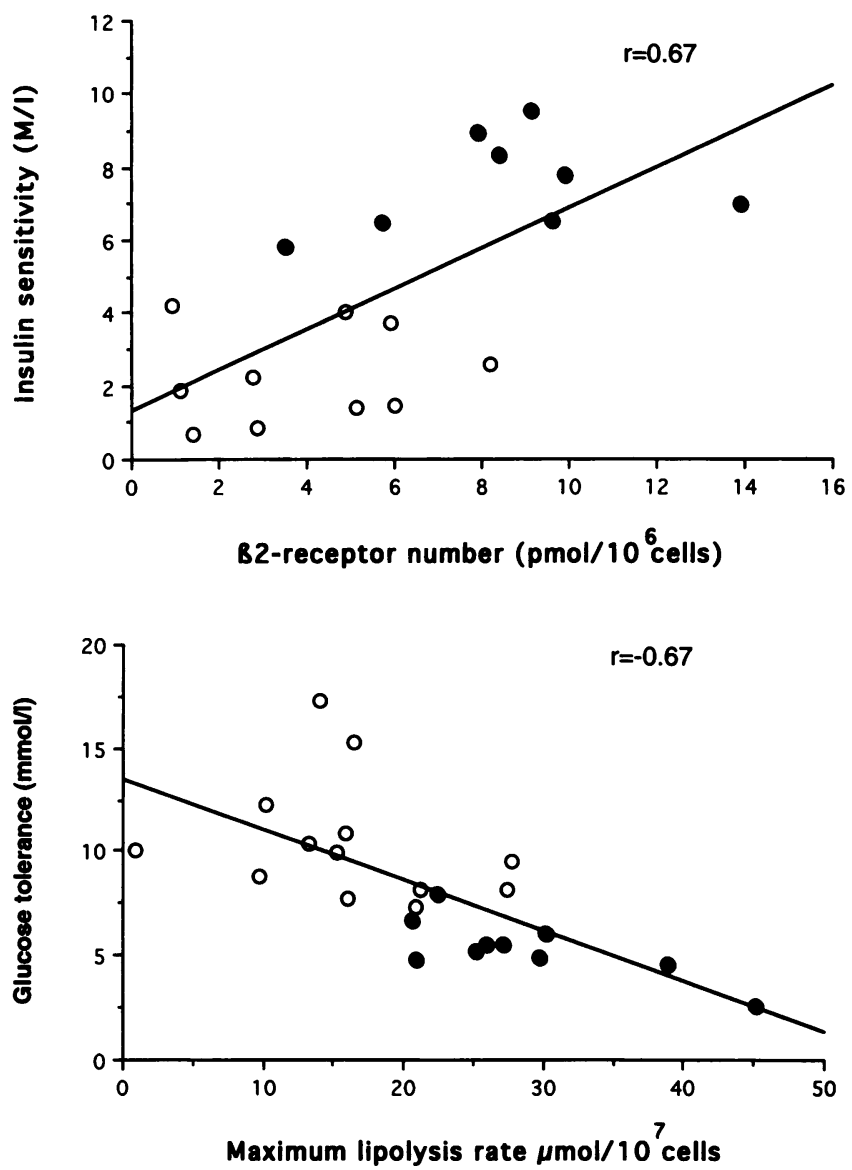

Figure 6. Relationship between insulin sensitivity and $\beta 2$-receptor number (upper panel) and maximum stimulated lipolysis rate vs oral glucose tolerance (lower panel) in subjects with the metabolic syndrome $(0)$ and healthy controls $(\bullet)$. A correlation was statistically tested using linear regression analysis.

What is the clinical relevance of these findings with catecholamine action? In a multiple stepwise regression analysis, the described defects, reduced $\beta 2$-receptor expression, and maximum lipolytic capacity, contributed significantly to the variations in insulin sensitivity and glucose tolerance which are two of the most important manifestations of insulin action and carbohydrate metabolism in the metabolic syndrome. Since three subjects were on treatment for hypertension, blood pressure was not included in the equation. Together with body mass index and fasting plasma insulin, the $\beta 2$-receptor number accounted for $80 \%$ of the variations in insulin sensitivity (i.e., partial $r^{2}$ ). Maximum lipolytic capacity accounted (together with basal lipolysis rate) for $77 \%$ of the variation in glucose tolerance. Future studies of catecholamine induced lipolysis in vivo are necessary to further elucidate the relevance of these findings. It is, however, of interest to note that a blunted in vivo lipolytic response to catecholamines has been found in subjects with abdominal obesity but not in subjects with lower-body obesity (42).

The relationship between the $\beta 2$-receptor defect and insulin resistance might be causal. A decreased $\beta 2$-receptor sensitivity may be a primary cellular defect which is compensated by increased sympathetic activity as described recently in healthy subjects (36). The increased catecholamine levels can in turn cause insulin resistance as reviewed by Smith and Lager (9) and be of importance for the pathophysiology of the metabolic syndrome. On the other hand, the hyperinsulinemia in the insulin-resistant subjects might selectively downregulate $\beta 2$-receptors in fat cells. There is experimental evidence that $\beta$-receptors in human fat cells are very sensitive to downregulation by insulin (28). The relationship between glucose intolerance and the postreceptor defect in lipolysis action is less readily explained since the molecular events that control activation of the hormone sensitive lipase are not well understood, nor the final metabolism of glucose in different tissues. One possibility is that there is some common defect in these late events in carbohydrate and lipid metabolism.

It is tempting to speculate that adipocyte catecholamine resistance is a primary defect causing a compensatory increase in sympathetic drive which promotes the pathophysiological changes of the metabolic syndrome. A decreased lipolytic responsiveness to noradrenaline in abdominal fat cells has previously been demonstrated in healthy elderly male subjects when compared with young healthy male subjects (43). This was due to changes at the level of protein kinase-hormone sensitive lipase and was accompanied by in vivo catecholamine resistance during exercise. In young healthy subjects we have found $\beta 2$ receptor mediated resistance to catecholamine action which also was compensated for by increased catecholamine levels during exercise (36). If lipolytic catecholamine resistance and compensatory sympathetic hyperactivity is of importance for the development of the metabolic syndrome it appears, thus, that the simultaneous presence of the two lipolytic defects described would be required. In the present study there were no significant differences in the resting plasma catecholamine levels. Unfortunately, an attempt at performing a standardized submaximal exercise test failed since too few of the obese subjects were able to complete the examination.

How do the present data agree with the so-called Randle hypothesis? This suggests a role of elevated free fatty acid levels in promoting insulin resistance by substrate competition (44), which might be of importance in the metabolic syndrome as discussed $(3,4,12)$. We presently observed normal fasting levels of glycerol and free fatty acids in plasma which is in accordance with the observed lipolysis defect (i.e., despite the increased fat mass, the lipid levels in the fasting state are not elevated in the metabolic syndrome due to the blunted catecholamine action). However, meal suppression of plasma-free fatty acids may be impaired due to insulin resistance and free fatty acids in plasma might be elevated after exercise and mental stress due to a high sympathetic drive and increased fat mass. Unfortunately the present in vitro study was not designed to answer such questions. Furthermore, the finding of increased basal lipolysis rates could be considered as a potential link to the Randle hypothesis.

This study was on subcutaneous abdominal fat cells from elderly male subjects. We do not know how it relates to lipolysis in other adipose regions or to catecholamine action in other target tissues. However, the $\beta 2$-receptor defect may be present in other fat depots of metabolic syndrome patients since there is a strong correlation between $\beta 2$-receptor activity in subcutaneous and visceral fat cells of healthy subjects (36). Furthermore, it remains to be elucidated if women or younger men with the metabolic syndrome also are resistant to catecholamines in vitro.

In conclusion, the present study demonstrates decreased ability of catecholamines to stimulate lipolysis in fat cells due 
to multiple defects in lipolysis regulation in obese elderly men suffering from the metabolic syndrome. The catecholamine resistance is secondary to a reduced expression of $\beta 2$-adrenoceptors in combination with a decreased ability of cyclic AMP to activate the hormone sensitive lipase. These defects may contribute to the development of severe manifestations of the syndrome such as glucose intolerance and insulin resistance.

\section{Acknowledgments}

This study was supported by grants from the Swedish Medical Research Council, the Swedish Diabetes Association, the Karolinska Institute, the Foundations of Axel and Margareta Axelson-Johnsson, Osterman, Wiberg, Nordic Insulin, Hoechst, Old Female Servants, Gojle, King Gustav V, and Trygg-Hansa.

\section{References}

1. Landsberg, L. 1989. Obesity, metabolism, and hypertension. Yale J. Biol. Med. 62:511-519.

2. Stern, M. P., and S. M. Haffner. 1986. Body fat distribution and hyperinsulinemia as risk factors for diabetes and cardiovascular disease. Arteriosclerosis. 6:123-130.

3. Björntorp, P. 1991. Metabolic implications of body fat distribution. Diabetes Care. 14:1132-1143.

4. DeFronzo, R. A., and E. Ferranini. 1991. Insulin resistance. A multifaceted syndrome responsible for NIDDM, obesity, hypertension, dyslipidemia and atherosclerotic cardiovascular disease. Diabetes Care. 14:173-194.

5. Black, H. R. 1990. The coronary artery disease paradox: the role of hyperinsulinemia and insulin resistance and implications for therapy. $J$. Cardiovasc. Pharmacol. 15:S26-S38.

6. Reaven, G. M. 1988. Role of insulin resistance in human disease. Diabetes. 37:1595-1607.

7. Thorburn, A. W., B. Gumbiner, F. Bulacan, G. Brechtel, and R. R. Henry. 1991. Multiple defects in muscle glycogen synthase activity contribute to reduced glycogen synthesis in non-insulin dependent diabetes mellitus. J. Clin. Invest. 87:489-495.

8. Groop, L. C., M. Kankuri, C. Schalin-Jäntti, A. Ekstrand, P. Nikula-Ijäs, E. Widén, E. Kuismanen, J. Eriksson, A. Franssila-Kallunki, C. Saloranta, and S. Koskimies. 1993. Association between polymorphism of the glycogen synthase gene and non-insulin-dependent diabetes mellitus. $N$. Engl. J. Med. 328:10-14.

9. Smith, U., and I. Lager. 1989. Insulin-antagonistic effects of counterregulatory hormones: clinical and mechanistic aspects. Diabetes Metab. Rev. 5:511525 .

10. Modan, M., and H. Halkin. 1991. Hyperinsulinemia or increased sympathetic drive as links for obesity and hypertension. Diabetes Care. 14:470-487.

11. Kissebah, A. H. 1991. Insulin resistance in visceral obesity. Int. J. Obes. 15:109-115.

12. Frayn, K. N., and S. W. Coppack. 1992. Insulin resistance, adipose tissue and coronary heart disease. Clin. Sci. 82:1-8.

13. Arner, P., T. Pollare, and H. Lithell. 1991. Different aetiologies of type 2 (non-insulin-dependent) diabetes mellitus in obese and non-obese subjects. Diabetologia. 34:483-487.

14. Pollare, T., H. Lithell, and C. Berne. 1990. Insulin resistance is a characteristic feature of primary hypertension independent of obesity. Metabolism 39:167-174.

15. Campbell, P. J., and M. G. Carlson. 1993. Impact of obesity on insulin action in NIDDM. Diabetes. 42:405-410.

16. Kohrt, W. M., J. P. Kirwan, M. A. Staten, R. E. Bourey, D. S. King, and J. O. Holloszy. 1993. Insulin resistance in aging is related to abdominal obesity. Diabetes. 42:273-281.

17. Smith, U. 1992. Life style and genes-the key factors for diabetes and the metabolic syndrome. J. Intern. Med. 232:99-101.

18. Arner, P. 1992. Adrenergic receptor function in fat cells. Am. J. Clin. Nutr. 55:228S-236S.
19. Arner, P., O. Arner, and J. Östman. 1973. The effect of local anaesthetic agents on lipolysis by human adipose tissue. Life Sci. 13:161-169.

20. Rodbell, M. 1964. Metabolism of isolated fat cells. I. Effects of hormones on glucose metabolism and lipolysis. J. Biol. Chem. 239:375-380.

21. Di Girolamo, M., S. Mendlinger, and J. W. Fertig. 1971. A simple method to determine fat cell size and number in four mammalian species. Am. J. Physiol. 221:850-858.

22. Hirsch, J., and E. Gallian. 1968. Methods for determination of adipose cell size and number in man and animals. J. Lipid Res. 9:110-119.

23. Kather, H., E. Wieland, A. Scheurer, G. Vogel, U. Widenberg, and C. Joose. 1987. Influences of variation in total energy intake and dietary composition. J. Clin. Invest. 80:566-572.

24. Arner, P., J. Bolinder, J. Hellmér, and P. Engfeldt. 1986. Studies on human fat cell metabolism in small adipose tissue samples. In Methods in diabetes research, Vol II: clinical methods, W. L. Clarke, J. Larner, and S. L. Pohl, editors. John Wiley \& Sons, New York. 233-258.

25. Hellmér, J., H. Wahrenberg, and P. Arner. 1992. Stability over time of adrenergic sensitivity in isolated fat cells. Int. J. Obes. 16:23-28.

26. Hellmér, J., P. Arner, and A. Lundin. 1989. Automatic luminometric kinetic assay of glycerol for lipolysis studies. Anal. Biochem. 177:132-137.

27. Arner, P., E. Kriegholm, and P. Engfeldt. 1991. In vivo interactions between beta- 1 and beta- 2 adrenoceptors regulate catecholamine tachyphylaxia in human adipose tissue. J. Pharmacol. Exp. Ther. 259:317-322.

28. Engfeldt, P., J. Hellmér, H. Wahrenberg, and P. Arner. 1988. Effects of insulin on adrenoceptor binding and the rate of catecholamine-induced lipolysis in isolated human fat cells. J. Biol. Chem. 263:15553-15560.

29. Scatchard, G. 1948. The attractions of proteins for small molecules and ions. Ann. NY Acad. Sci. 51:660-672.

30. Munson, P., and D. Rodbard. 1980. LIGAND: a versatile computerized approach for characterization of ligand binding systems. Anal. Biochem 107:220-239.

31. Féve, B., L. J. Emorine, F. Lasnier, N. Blin, B. Baude, C. Nahmias, A. D. Strosberg, and J. Pairault. 1991. Atypical $\beta$-adrenergic receptor in 3T3-F442A adipocytes. J. Biol. Chem. 266:20329-20336.

32. Tate, K. M., M.-M. Briend-Sutren, L. J. Emorine, C. Delavier-Klutchko, S. Marullo, and A. D. Strosberg. 1991. Expression of three human $\beta$-adrenergicreceptor subtypes in transfected chinese hamster ovary cells. Eur. J. Biochem. 196:357-361.

33. Arner, P., L. Hellström, H. Wahrenberg, and M. Brönnegård. 1990. Betaadrenoceptor expression in human fat cells from different regions. J. Clin. Invest. 86:1595-1600.

34. Labarca, C., K. Paigen. 1980. A simple rapid and sensitive DNA assay procedure. Anal. Biochem. 102:344-352.

35. Durnamn, D. M., and R. D. Palmiter. 1983. A practical approach for quantitating specific mRNAs by solution hybridization. Anal. Biochem. 131:385-393.

36. Lönnqvist, F., H. Wahrenberg, L. Hellström, S. Reynisdottir, and P. Arner. 1992. Lipolytic catecholamine resistance due to decreased $\beta 2$-adrenoceptor expression in fat cells. J. Clin. Invest. 90:2175-2186.

37. Arch, J. R. S. 1989. The brown adipocyte $\beta$-adrenoceptor. Proc. Nutr. Soc. 48:215-223.

38. Langin, D., M. P. Portillo, J-S. Saulnier-Blache, and M. Lafontan. 1991 Coexistance of three $\beta$-adrenoceptor subtypes in white fat cells of various mammalian species. Eur. J. Pharmacol. 199:291-301.

39. Hollenga, C., F. Brouwer, and J. Zaagsma. 1991. Differences in functional cyclic AMP compartments mediating lipolysis by isoprenaline and BRL 37344 in four adipocyte types. Eur. J. Pharmacol. 200:325-330.

40. Mauriège, P., J. P. Després, D. Prud'homme, M. C. Pouliot, M. Marcotte, A. Tremblay, and C. Bouchard. 1991. Regional variation in adipose tissue lipolysis in lean and obese men. J. Lipid Res. 32:1625-1633.

41. Arner, P. 1988. Control of lipolysis and its relevance to development of obesity in man. Diabetes Metab. Rev. 4:507-515.

42. Jensen, M. D., M. W. Haymond, R. A. Rizza, P. E. Cryer, and J. M. Miles 1989. Influence of body fat distribution on free fatty acid metabolism in obesity. J. Clin. Invest. 83:1168-1173.

43. Lönnqvist, F., B. Nyberg, H. Wahrenberg, and P. Arner. 1990. Catecholamine-induced lipolysis in adipose tissue of the elderly. J. Clin. Invest. 85:16141621 .

44. Randle, P. J., P. B. Garland, C. N. Hales, and E. A. Newsholme. 1963. The glucose fatty-acid cycle: its role in insulin sensitivity and the metabolic disturbances of diabetes mellitus. Lancet. 1:785-789. 